\title{
An Open Label, Randomized, Parallel Efficacy, Active Controlled Clinical Study to Compare the Efficacy of Nirgundi Patra and Erandamuladi Niruha Basti in Yoga Basti Pattern in Gridhrasi (Sciatica)
}

\author{
Research Article
}

\section{Vishnu B1 $^{*}$, James Chacko², Mahesh C Kundagol'3, Devipriya Soman ${ }^{4}$}

1. P.G Scholar, 2. Professor \& HOD, 3. Associate Professor, 4. Assistant Professor, Department of Kayachikitsa (General Medicine), School of Ayurveda, Amrita Vishwa Vidyapeetham, Kerala, India.

\begin{abstract}
It is estimated that Low back pain afflicts nearly two thirds of the Indian population at some point in their life. Erandamuladi Niruha Basti is a widely practiced and proven formulation that is used in Gridhrasi (Sciatica). It contains more than 20 ingredients, which can be a daunting task for an ayurvedic practitioner in a clinic to procure. Hence the literary search was done with a view to find out other effective formulations which were preferably single drug formulations. Nirgundi patra Kashaya was mentioned by acharya Chakrapanidatta in Vatavyadhi Adhikarana of Chakradatta. Nirgundi itself has anti-inflammatory and analgesic properties, so this Kashaya was selected as a Basti to be compared with Erandamuladi Niruha Basti in Yoga Basti pattern. 30 patients were randomized into two groups, Group A and Group B based on a set of inclusion and exclusion criteria. Group A was given Nirgundi Patra Kashaya Niruha and Murchita Tila Taila Anuvasana and Group B patients were given Erandamuladi Niruha and Murchita Tila Taila Anuvasana. Objective and Subjective parameters were evaluated before the start of the treatment and at the end of the treatment. The parameters were evaluated using relevant statistical tests. The result showed that even though all the patients had relief after the treatment, he percentage of relief was more across all parameters in case of Group B. This showed that, Nirgundi patra Kashaya was effective in the treatment of Gridhrasi in Basti formulation, but, Erandamuladi Niruha Basti produced much significant relief.
\end{abstract}

Key Words: Nirgundi, Erandamuladi, Yoga basti, Gridhrasi, Sciatica, Basti.

\section{Introduction}

Sciatica is a clinical condition characterized by low back ache with pain radiating to either lower limbs. It can be associated with numbness or paresthesia of lower extremities. Not all cases of lower back ache can be termed as sciatica, but all the cases of sciatica will have lower back ache. In the modern world, because of the daily grind and household chores, lower back problems have become a common occurrence. (1)

Considering sciatica as an autonomous illness, it is generally a typical condition with the life time occurrence fluctuating from $1.6-43.4 \%$. (2) It is an agonizing condition influencing the low back region with radiating pain towards legs, either one leg or bilaterally. In Ayurveda, these manifestations have similarities with that of the disease Gridhrasi.

Gridhrasi is one among the 80 kinds of nanatmaja vata vikaras, however vata-kaphaja type was mentioned in particular. The name itself was advanced from the disposition in walk of patients like that of a Gridhra (vulture). The torment is additionally

\section{* Corresponding Author:}

\section{Vishnu B}

Assistant Professor,

Shri Dhanwantry Ayurvedic College and Hospital

Chandigarh, India.

Email Id: drvishnub.ay@gmail.com agonizing and tearing like that of a vulture tearing flesh for its sustenance.

The cardinal side effects of Gridhrasi incorporates Sthamba (stiffness), Ruk (pain), Toda (pricking pain), Grahana (catching pain) and Spandana (numbing sensation), with pain radiating from Sphik (hip), Kati (lowback), Prishta (back), Uru (thighs), Janu (knee joint), Jangha (calf muscles) up to Padam (foot) in order and the patient finds it difficult to walk. In kapha associated condition, Aruchi (absence of taste), Tandra(stupor) and Gourava(heaviness) are seen. Lifting of lower limbs are restricted in majority of the cases. (3)

In Ayurvedic practice, Basti has been mentioned as the most effective treatment for Gridhrasi by all acharyas. Basti is also the most important treatment for vatavyadhi. It is said as the ardha chikitsa (half treatment) for vatavyaadhi. $(4,5)$

Erandamuladi Niruha Basti is a Basti which is generally practiced for the treatment of Gridhrasi. Many Studies have been done to assess its efficacy in the treatment of Gridhrasi and was found to be effective. (6,7) But Erandamuladi Basti is a comparatively expensive preparation and it has a number of ingredients which can be difficult to procure.

In our current treatment practice, we are facing an acute shortage of raw materials. This increases the price of raw drugs in the market and thus increases the cost of treatment. Finding a treatment modality which is 
cost efficient while being therapeutically effective is important in current scenario.

Keeping in mind conditions such as increasing cost of treatment and limitations of present-day practice, this study has been undertaken to humbly suggest cheaper and effective alternative to Erandamuladi Niruha Basti.

Nirgundi Patra Kashaya has been mentioned by many acharyas as effective in curing even long standing and severe cases of Gridhrasi. (8) Many studies have been done on the analgesic and anti-inflammatory activity of the leaves of Nirgundi (Vitex negundo). In all studies it was proved conclusively that the leaf extract of Nirgundi has excellent analgesic and antiinflammatory action. (9)

For this study Nirgundi Patra Kashaya Basti will be compared with Erandamuladi Niruha Basti, which has been established as effective in Gridhrasi by many previous studies.

\section{Aims and Objectives}

- To assess the efficacy of Nirgundi patra Kashaya Basti in Grdhrasi (Sciatica).

- To assess the efficacy of Erandamuladi Niruha Basti in Gridhrasi (Sciatica).

- To compare the efficacy of Nirgundi patra Kashaya Basti and Erandamuladi Niruha Basti in Yoga Basti pattern in two individual sample groups of 15.

\section{Hypothesis}

- Alternate Hypothesis, H1 = Nirgundi patra Niruha Basti is effective than Erandamuladi Niruha Basti in Gridhrasi.

- Null Hypothesis, H0 = Nirgundi patra Niruha Basti is not effective than Erandamuladi Niruha Basti in Gridhrasi.

\section{Materials and Methods}

\section{Inclusion Criteria}

- Patients having signs and symptoms of Gridhrasi like Stambha, Ruk, Toda and Spandana starting from Sphik (hip) \& extend through Kati (lowback), Prishta (buttocks), Uru (thighs), Janu (Knee), Jangha (Calf), Padam (foot) in an order.

- Positive SLR test.

- Patient having Sciatica with mild to moderate osteoporotic changes and where surgical interventions are not absolutely necessary and medical management are suggested.

- Patient between the age group of 20-70 years of either sex.

- Conditions mentioned under ICD codes M54.30, M54.31, M54.32, M54.40, M54.41, M54.42

\section{Exclusion Criteria}

- Fracture and Dislocation of vertebrae.

- Deformities and congenital defects.

- Known case of TB spine.

- Known case of Neoplasm of spine.

- Severe osteoporotic degeneration.

1.Contra-indicated for Basti karma

\section{Laboratory and Radiological Assessment}

To meet the exclusion criteria, the following investigations were done: - $\mathrm{Hb} \%$, TC, DC, ESR, X-ray Lumbo Sacral Spine (AP \& Lateral).

Assessment criteria

Table 1: Table of Assessment criteria used in the study

\begin{tabular}{|c|c|c|c|}
\hline SI No. & $\begin{array}{c}\text { Objective } \\
\text { symptoms }\end{array}$ & Parameters & Gradation \\
\hline \multirow{5}{*}{1} & \multirow{5}{*}{$\begin{array}{l}\text { Oswestry } \\
\text { Disability } \\
\text { Index }\end{array}$} & $\begin{array}{c}0-20 \%- \\
\text { Minimal disability }\end{array}$ & 0 \\
\hline & & $\begin{array}{c}21-40 \%- \\
\text { Moderate disability }\end{array}$ & 1 \\
\hline & & $\begin{array}{c}41-60 \%- \\
\text { Severe disability }\end{array}$ & 2 \\
\hline & & $61-80 \%$ - Crippled & 3 \\
\hline & & $\begin{array}{c}81-100 \%- \\
\text { Bed bound or } \\
\text { exaggerated }\end{array}$ & 4 \\
\hline \multirow{5}{*}{2} & \multirow{5}{*}{ SLR } & $81^{0}-100^{0}$ & 0 \\
\hline & & $61^{0}-80^{0}$ & 1 \\
\hline & & $41^{0}-60^{0}$ & 2 \\
\hline & & $21^{0}-40^{0}$ & 3 \\
\hline & & $0^{0}-20^{0}$ & 4 \\
\hline \multirow{2}{*}{3} & \multirow{2}{*}{ Lasegue's } & Negative & 0 \\
\hline & & Positive & 1 \\
\hline \multirow{2}{*}{4} & \multirow{2}{*}{ Gaenslen's } & Negative & 0 \\
\hline & & Positive & 1 \\
\hline \multirow{2}{*}{5} & \multirow{2}{*}{ Schober's } & More than 15 & 0 \\
\hline & & Less than 15 & 1 \\
\hline \multicolumn{4}{|c|}{ Subjective Symptoms } \\
\hline \multirow{4}{*}{1} & \multirow{4}{*}{$R u k$} & Nil & 0 \\
\hline & & $\begin{array}{l}\text { Mild (Grimace/ } \\
\text { Wince) }\end{array}$ & 1 \\
\hline & & $\begin{array}{c}\text { Moderate } \\
\text { (Withdrawal) }\end{array}$ & 2 \\
\hline & & $\begin{array}{c}\text { Severe (Refusal to } \\
\text { palpate) }\end{array}$ & 3 \\
\hline \multirow{4}{*}{2} & \multirow{4}{*}{ Toda } & No response & 0 \\
\hline & & Grimace/Wince & 1 \\
\hline & & Withdrawal & 2 \\
\hline & & Refusal to palpation & 3 \\
\hline \multirow{4}{*}{3} & \multirow{4}{*}{ Stambha } & Absent & 0 \\
\hline & & Mild (Local rigidity) & 1 \\
\hline & & $\begin{array}{l}\text { Moderate (Rigidity in } \\
\text { regions other than } \\
\text { affected region) }\end{array}$ & 2 \\
\hline & & $\begin{array}{l}\text { Severe (Generalized } \\
\text { rigidity) }\end{array}$ & 3 \\
\hline \multirow{4}{*}{4} & \multirow{4}{*}{ Spandana } & Absent & 0 \\
\hline & & $\begin{array}{l}\text { Mild (Local } \\
\text { numbness) }\end{array}$ & 1 \\
\hline & & $\begin{array}{l}\text { Moderate (Numbness } \\
\text { in regions other than } \\
\text { affected region) }\end{array}$ & 2 \\
\hline & & $\begin{array}{c}\text { Severe (Generalized } \\
\text { numbness) }\end{array}$ & 3 \\
\hline
\end{tabular}

Calculating the percentage relief

[Mean Value of BT-Mean Value of AT] / Mean Value of BT X 100 
External Treatment

Table 2: Table of External treatments given to the patient, an overview

\begin{tabular}{|c|c|c|}
\hline Groups & $\mathbf{A}$ & B \\
\hline $\begin{array}{l}\text { Amapachana } \\
\text { (Correcting } \\
\text { Digestive } \\
\text { Process) }\end{array}$ & $\begin{array}{l}\text { Trikatu choorna } \\
\text { internally and } \\
\text { Kolakulathadi } \\
\text { choorna lepa } \\
\text { externally for } \\
\text { three days. }\end{array}$ & $\begin{array}{l}\text { Trikatu choorna } \\
\text { internally and } \\
\text { Kolakulathadi } \\
\text { choorna lepa } \\
\text { externally for } \\
\text { three days. }\end{array}$ \\
\hline $\begin{array}{l}\text { Poorvakarma } \\
\text { (Pre-preparatory } \\
\text { Process) }\end{array}$ & $\begin{array}{l}\text { Localized } \\
\text { abhyanga with } \\
\text { murchita tila } \\
\text { taila. }\end{array}$ & $\begin{array}{l}\text { Localized } \\
\text { abhyanga with } \\
\text { murchita tila } \\
\text { taila. }\end{array}$ \\
\hline $\begin{array}{l}\text { Pradhanakarma } \\
\text { (Therapeutic } \\
\text { Process) }\end{array}$ & $\begin{array}{l}\text { Nirgundi Patra } \\
\text { Basti as Niruha, } \\
\text { Murchita Tila } \\
\text { taila as } \\
\text { Anuvasana. }\end{array}$ & $\begin{array}{l}\text { Erandamuladi } \\
\text { Basti as Niruha, } \\
\text { Murchita Tila } \\
\text { Taila as } \\
\text { Anuvasana. }\end{array}$ \\
\hline $\begin{array}{l}\text { Paschat Karma } \\
\text { (Post-therapeutic } \\
\text { Process) }\end{array}$ & $\begin{array}{l}\text { Patient was } \\
\text { advised to take } \\
\text { Rice gruel after } \\
\text { Niruha Basti }\end{array}$ & $\begin{array}{l}\text { Patient was } \\
\text { advised to take } \\
\text { Rice gruel after } \\
\text { Niruha Basti }\end{array}$ \\
\hline Follow Up & $\begin{array}{l}2 \text { follow ups } 15 \text { th } \\
\text { day and } 30 \text { th day } \\
\text { after treatment }\end{array}$ & $\begin{array}{l}2 \text { follow ups } 15 \text { th } \\
\text { day and } 30 \text { th day } \\
\text { after treatment }\end{array}$ \\
\hline
\end{tabular}

\section{Dose of Basti}

Dose of Niruha Basti is decided as 1 to $1 \& 1 / 4$ prastha $(768-960 \mathrm{ml})(10)$

Dose of Anuvasana Basti is decided as $1 \& 1 / 2$ pala $(144 \mathrm{ml})(11)$

\section{Statistical Analysis}

Assessment criteria were analyzed using Wilcoxon test for individual groups and Mann-Whitney test for between the groups.

\section{Observations}

For the present study, 30 patients were registered in two groups (Group A and Group B). Among them, 15 patients completed treatment in each group. The observation and results of 30 patients are given below.

\section{Age}

In this study, 10 patients from Group A were between the age group of 50-59, 2 patients were between the age group of 20-29, 1 patient was between the age group of 30-39 and 2 patients were between the age group of 40-49.
In Group B, 9 patients were between the age group of 50-59, 1 patient was between the age group of $40-49,4$ patients were between the age group of 30-39 and 1 patient was between the age group of 20-29.

\section{Gender}

In this study, 6 males were enrolled in Group A while, 4 males patients were enrolled in Group B. 9 female patients were enrolled in Group A while, 11 female patients were enrolled in Group B.

\section{Education}

Group A had 1 patient who had a post Graduate degree, 7 who were undergraduates and 7 who were at SSLC level.

Group B had 2 Post Graduates, 11 undergraduates and 2 patients who were at SSLC level.

\section{Economic status}

In Group A, 8 patients were from the below poverty line class and 7 were from the middle class; while in Group B, 2 patients were from the below poverty line class, 1 was from the above poverty line, 11 were from middle class and 1 was from the rich class.

\section{Occupation}

In Group A, 1 patient was an active worker, 2 were sedentary workers, 3 were involved in long standing occupations, 4 were involved in long sitting occupations, 1 was involved with lifting of weights and 2 each were involved with travelling and other hazardous occupations.

In Group B, 2 patients were active workers, 2 were sedentary workers, 3 were involved in long standing occupations, 6 were involved with long sitting occupations and 1 each had occupations associated with night shifts and travelling.

\section{Diet}

In Group A, 2 patients were vegetarian and 13 ate mixed food; while in Group B, 6 patients were vegetarian and 9 ate mixed food.

\section{Bowel Habits}

In Group A 6 patients had normal bowel habits (1-2 times/day) and 9 had constipation. While in Group B 10 patients had normal bowel habit and 5 had constipation.

\section{Results}

Table 3: Table of results of the study 


\begin{tabular}{|l|c|c|c|}
\hline Lasegue's & 0.87 & 0.6 & 31.03 \\
\hline Schober's & 2.4 & 1.2 & 50 \\
\hline Gaenslen's & 0.67 & 0.4 & 40.2 \\
\hline Ruk & 2 & 0.87 & 56.5 \\
\hline Toda & 1.73 & 0.53 & 68.3 \\
\hline Stambha & 0.73 & 0.23 & 45.9 \\
\hline Spandana & 0.87 & 0.47 & \\
\hline
\end{tabular}

GROUP B- Erandamuladi Group

\begin{tabular}{|l|c|c|c|}
\hline & Mean BT & Mean AT & Percentage Relief (\%) \\
\hline SLR & 3.53 & 2.33 & 33.9 \\
\hline ODI & 3 & 1.7 & 43.3 \\
\hline Lasegue's & 0.73 & 0.4 & 45 \\
\hline Schober's & 2.33 & 0.43 & 60 \\
\hline Gaenslen's & 0.73 & 0.2 & 72 \\
\hline Ruk & 2.67 & 1 & 62 \\
\hline Toda & 1.8 & 0.33 & 81 \\
\hline Stambha & 0.78 & 0.21 & 73.07 \\
\hline Spandana & 0.73 & 0.13 & 82 \\
\hline
\end{tabular}

Comparing both the Groups, the percentage relief across the parameters were significantly more in Group B among all parameters. By analyzing all the parameters, it can be concluded that Group B had more significant outcome than Group A.

Analysis of Results

Table 4: Statistical Analysis

\section{Test Statistics}

\begin{tabular}{|l|c|c|c|c|c|c|c|c|c|} 
& SLR & ODI & Lasegue's & Schober's & Gaenslen's & Ruk & Toda & Stambha & Spandana \\
\hline Mann-Whitney U & 91 & 93 & 90 & 92.5 & 90 & 100.5 & 86.5 & 97.5 & 90 \\
\hline Wilcoxon W & 211 & 213 & 210 & 212.5 & 210 & 220.5 & 206.5 & 217.5 & 210 \\
\hline Z & -1.046 & -0.96 & -1.077 & -1.027 & -1.175 & -0.597 & -1.257 & -0.898 & -1.175 \\
\hline Asymp. Sig. (2-tailed) & 0.296 & 0.337 & 0.281 & 0.305 & 0.24 & 0.55 & 0.209 & 0.086 & 0.24 \\
\hline $\begin{array}{l}\text { Exact Sig. [2*(1-tailed } \\
\text { Sig.)] }\end{array}$ & $0.389 \mathrm{~b}$ & $0.436 \mathrm{~b}$ & $0.367 \mathrm{~b}$ & $0.412 \mathrm{~b}$ & $0.367 \mathrm{~b}$ & $0.624 \mathrm{~b}$ & $0.285 \mathrm{~b}$ & $0.053 \mathrm{~b}$ & $0.367 \mathrm{~b}$ \\
\hline
\end{tabular}

From the above statistical evaluations, it becomes clear that Nirgundi patra Kashaya Basti and Erandamuladi Niruha Basti show significant results in the management of Gridhrasi (Sciatica). Objective of this study was to compare the efficacy between two groups. When the outcome measures were compared, the Group B was significant in all the assessment parameters.

The objective of this study was to compare the efficacy between two groups. When the outcome measures were compared using Mann Whitney U test, Group B was significant in all the assessment parameters.

So, we can conclude that Group B, ie., Erandamuladi Niruha Basti was more effective in the management of Gridhrasi (sciatica).

\section{Discussion}

Among the Tridoshas, vata is the most important one as it is capable of controlling other two doshas (humors). When analyzing nanatmaja vikaras (multitude of diseases) in relation to each doshas, it is clear that vata causes comparatively larger number of diseases. The Vyadhis (diseases) related to vata Dosha are caused by two main factors, dhatukshaya (emaciation of body tissues) and margavarodha (obstruction to the channels of circulation. (12)

'Sciatica' is the most apt disease to which Gridhrasi can be co-related due to the similarity of symptoms. The term is also used to refer to pain anywhere along the course of the sciatic nerve. This disease will exhibit symptoms unilaterally or bilaterally along the lower limb.

The chikitsa sutra (treatment principle) of Gridhrasi is pachana (correcting the digestive process), then urdhwa (upward) and adha shodhana (downward elimination) and finally Basti. According to ayurvedic principles, since vata is the main dosha (humor) involved in the samprapti (pathogenesis) of Gridhrasi, drugs should possess ushna (hot) and snigdha (unctuous) property. $(13,14)$ No specific commentary was found on basti chikitsa mentioned in Gridhrasi. In Ayurvedic treatment protocols, there are several routes for administration of drugs, according to site of dosha dushti (vitiation of humors) such as Ghranam (nose), Vaktram (mouth) and Gudam (rectal). Gridhrasi is considered a Pakwasaya (large intestine) and Kati asrita (hip) vyadhi. So, the best route of administration of drugs are through Guda, in the form of basti according to Ayurveda. (15) 


\section{Discussion on probable mode of action of the drug}

Nirgundi (Vitex negundo (L.)) contains many alkaloids and essential oils which has properties like, anti-inflammatory, antispasmodic, analgesic, antihistamine releasing etc. It is Tikta (bitter), Katu (pungent), Kashaya guna (astringent) and Ushna veerya (hot potency) in nature. It possesses Kaphashamaka (pacifies kapha humor), Vatashamaka (pacifies vata humor), shophahara (anti-inflammatory), and Anulomana (laxative) properties. (16) This explains the exemplary effectiveness of Nirgundi in Vata vyadhis. It is generally used in the form of swarasa (juice) internally or as paste for external application. Main aim of the use is to reduce the swelling which aggravates the pain caused by inflamed sciatic nerves.

Erandamuladi Niruha Basti is a multiple drug compound formulation having more than 20 ingredients. The chief ingredients amongst them are Erandamula (Ricinus communis L.), Palasha (Butea monosperma (Lam.) Taub), Hrasva panchamula, Rasna (Alpinia galangal (L.) Willd.), Ashwagandha (Withania somnifera (L.) Dunal.), Guduchi (Tinospora cordifolia (Thunb.) Miers.) and Atibala (Abutilon indicum (Link.) Sweet.). (17)

On analysis of the chemical constituents present in the drugs shows us that it contains, alkaloids, terpenoids, tannin, steroidal alkaloids, flavonoids etc. This lets us arrive at a conjecture regarding the possible properties of the compound formulation. (18) Our inference is strengthened by the analysis of the individual drugs of Erandamuladi Niruha Basti, the chief ingredient among which is Erandamula, which is vata-kapha hara (reducing vata humor), ushna veerya (hot potency) and shothahara (anti-inflammatory) in nature. (19)

\section{Discussion on probable mode of action of Basti}

Basti chikitsa (medicated enema) is considered as Ardha chikitsa (half therapy) or Poorna chikitsa (complete therapy) of vata vyadhi. It is of two types, Niruha basti (Decoction enema) and Anuvasana / Sneha basti (oil enema). Action of Niruha basti is to remove Tridoshas from pakwasaya which is considered as main site of vata dosha. $(20,21)$

In Gridhrasi the main dosha involved is Vata and Kapha and to eliminate them from pakwasaya the best method is niruha basti. Apanavata anulomanam, Agni deepanam and pakwasaya sthita dosha nirharana is attained through niruha basti. (22)

Only after attaining niramata and deepthagni, sneha basti is indicated. By deepana, pachana and urdhwa adha shodhana, the marga avarana is removed and srotas get vishudha and to this when Sneha basti is done it becomes extremely vata shamana. (23)

The utbhava sthana of Gridhrasi is usually pakwasaya and the vyakta sthana is kati and sakthi. These three sites, i.e., pakwasaya, kati and sakthi are the major sites of vata dosha as per the classics. Classical references also provide the information that basti is the agrya chikitsa for vata. So shamana aushadha prayoga through guda might show its best effect in pakwashaya asrita rogas. (24)
Presently while considering the contemporary logical investigation on the activity of niruha and anuvasana basti, a likely speculative comprehension can be made.

Colon Targeted Drug Delivery System (CDDS), is the latest innovation of contemporary medical researchers. For aeons, researchers have been searching for a solution to deliver the maximum quantity of drug effectively into systemic circulation. Present day drugs first arrive in the stomach, where it gets acted upon by gastric juices and in such a hostile environment, the drug molecules get absorbed from the gastric mucosa. CDDS is a group of bio-engineered drugs which does not undergo breakdown in the stomach, rather continues on with its journey which culminates in large intestine where the active drug molecules are released to be absorbed by the intestinal mucosa. (25)

Retention of medication in rectum is through two ways, the trans-cellular course and para-cellular course. A take-up system in trans-cellular course relies upon lipophilicity of medications while para-cellular course depends upon drug dissemination through a space between epithelial cells. The short chain fatty acids (SCFA) and long chain fatty acids (LCFA) of medicated oils infused with herbal drugs, gets absorbed into systemic circulation through intestinal mucosal wall. $(26,27)$

Rectal administration of medications can also bypass hepatic first pass metabolism. The superior rectal vein drains the upper part of the rectum, into the portal vein and subsequently into the liver. But, the lipid-based medications when regulated as Niruha Basti, will remain in contact with the rectum (especially center and inferior rectal area) for a more extended time period.

Middle and inferior rectal veins drain the lower part of the rectum and enter into the inferior vena cava and bypass the liver before entering the general circulation. This indicates that the drug administered in the lower part of the rectum can bypass the liver resulting in the avoidance of hepatic first pass metabolism, making it possible for the availability of a larger part of drug absorbed, into the systemic circulation.

From the inferior vena cava blood contains the absorbed drug reaches the heart, and later it passes out through arch of aorta. On reaching near the lumbar vertebrae, descending aorta branches to form lumbar artery. The lumbar artery and its branches then supply the vertebrae for nutrition and oxygenation.

So, after doing niruha basti, the drugs that might have been absorbed from the rectum thus could probably act on the lumbar vertebrae and its adjuvant intervertebral discs, there by accelerating the healing process and imparting the effect of drugs to that particular area. This is a probable hypothetical understanding in mode of action of niruha basti in Gridhrasi and it needs further research studies to prove its validity.

The comparative significance obtained in Erandamuladi Niruha Basti group might be due to 
specificity of its action in Gridhrasi proposed by acharyas as well as it's synergistic effect due to multiple drug compounds acting together.

\section{Conclusion}

Based on the observations made in the clinical study, the alternate hypothesis is rejected and null hypothesis is accepted. i.e., Null Hypothesis- "Nirgundi patra Niruha Basti is not effective than Erandamuladi Niruha Basti in Gridhrasi (sciatica)", has been accepted and the following conclusions were drawn.

- Maximum incidence of this disease was seen between age of 50-60.

- Both Nirgundi patra Niruha and Erandamuladi Niruha Basti was effective in the management of Gridhrasi (sciatica).

- Erandamuladi Niruha Basti was found to be statistically significant in the treatment of Gridhrasi (sciatica), when all the outcome measure was compared together.

- As Gridhrasi presents with dosha involvement of vata and vata-kaphaja, vata- kapha hara aushadas will have an upper hand in managing Gridhrasi.

- Nirgundi patra Kashaya and Erandamuladi Niruha Basti Yoga contains drugs which are vata kaphahara and shophahara in nature. These combinations do their best in the samprapti vighatana of Gridhrasi.

\section{Limitations and recommendations}

- The size of samples and time period were small to draw a solid conclusion. So the therapy can be tried in a large sample for appropriate duration to observe its proper efficacy.

- Follow up duration shall be extended to assess the recurrence.

- Nirgundi patra Kashaya Basti was effective in all the outcome measures. Further studies must be done to evaluate its potential.

- The efficacy of Nirgundi patra Kashaya orally also has to be analyzed.

\section{References}

1. Harrison's principles of internal medicine. 17th edition. New York; McGraw hill Publication; 2008. $107 \mathrm{p}$.

2. Valat JP, Genevay S, Marty M, Rozenberg S, Koes B. Sciatica. Best Pract Res Clin Rheumatol. Apr, $2010 ; 24(2) ; 241-52$. doi: 10.1016/ j.berh.2009.11.005. PMID: 20227645.

3. Yadavji Trikamji Acharya. Charaka Samhita of Agnivesha. Varanasi; Choukhambha Surbharati prakashana; 2011; 619p

4. Yadavji Trikamji Acharya. Charaka Samhita of Agnivesha. Varanasi; Choukhambha Surbharati prakashana; 2011; 619p
5. Indradeva Tripathy. Chakradatta of Chakrapanidatta; Chaukhambha Sanskrit Bhawan; 2011; 137p

6. B.A Lohith, Girish K.J. Clinical Study to assess the effect of Yoga basti in Gridhrasi. Int. J. Res. Ayur. P harm. $2013 ; \quad 4(1) ; \quad 50-53$. doi:10.7897/2277-4343.04123

7. Damayanthie Fernando KP, Thakar AB, Shukla VD. Clinical efficacy of Eranda Muladi Yapana Basti in the management of Kati Graha (Lumbar spondylosis). Ayu. 2013;34(1):36-41. doi:10.4103/0974-8520.115444

8. Indradeva Tripathy. Chakradatta of Chakrapanidatta; Chaukhambha Sanskrit Bhawan; 2011; 136p

9. Telang R S, Chatterjee S, Varshneya C. Study on analgesic and anti-inflammatory activities of Vitex negundo Linn.Indian J Pharmacol. 1999; 31(3); 63-366

10. Radhakrishna Parashar. Sharangadhar Samhita. 2012; Uttarakhand. 491p.

11. Radhakrishna Parashar. Sharangadhar Samhita. 2012; Uttarakhand. 491p.

12. Priyavrat Sharma. Charak Samhita of Agnivesha. 7th edition. Varanasi; Chaukhambha Orientalia; 2002; 467p.

13. Yadavji Trikamji. Charaka Samhita by Agnivesha. Varanasi; Chaukhamba Orientalia; 2009; 620p

14. Yadavji Trikamji. Sushruta Samhita by Susrutha. Varanasi; Chaukhamba surbharti Prakashana; 2010; $528 \mathrm{p}$.

15. Yadavji Trikamji. Charaka Samhita by Agnivesha. Varanasi; Chaukhamba Orientalia; 2009; 620p

16. Parveen kumar, Smita kumari. Pharmacological Properties of Nirgundi: A Review. International Journal of Ayurveda and Pharma Research. February, 2020; 8(2); 68-73

17. B.A Lohith, Girish K.J. Clinical Study to assess the effect of Yoga basti in Gridhrasi. Int. J. Res. Ayur. P harm. $2013 ; \quad 4(1) ; \quad 50-53$. doi:10.7897/2277-4343.04123

18. Dharmendra Kumar, Rajesh Kumar and Kumari Sharda. Medicinal property of Nirgundi. Journal of Pharmacognosy and Phytochemistry. 2018; 7(1S); 2147-2151.

19. B.A Lohith, Girish K.J. Clinical Study to assess the effect of Yoga basti in Gridhrasi. Int. J. Res. Ayur. Pharm. $\quad 2013 ; \quad 4(1) ; \quad 50-53$. doi:10.7897/2277-4343.04123

20. Yadavji Trikamji. Charaka Samhita by Agnivesha. Varanasi; Chaukhamba Orientalia; 2009; 619p

21. Indradeva Tripathy. Chakradatta by Chakrapanidatta; Chaukhambha Sanskrit Bhawan; 2011; 137p

22. Yadavji, Trikamji. Susruta Samhita by Susruta. Varanasi; Chaukhambha Sanskrit Sansthan; 2010; 527-528p.

23. Priyavrat Sharma. Charak Samhita of Agnivesha. 7th edition. Varanasi; Chaukhambha Orientalia; 2002; 591p. 
24. Priyavrat Sharma. Charak Samhita of Agnivesha 7th edition. Varanasi; Chaukhambha Orientalia; 2002; 591p.

25. Prasanth V.V, Jayaprakash. R, Sam T. Mathew. Colon Specific Drug Delivery Systems: A Review on Various Pharmaceutical Approaches. Journal of Applied Pharmaceutical Science. February, 2012; $02(01) ; 163-169$
26. Philip AK, Philip B. Colon targeted drug delivery systems: a review on primary and novel approaches. Oman Medical Journal. Apr, 2010; 25(2); 79-87. DOI: 10.5001/omj.2010.24.

27. Chourasia MK, Jain SK. Pharmaceutical approaches to colon targeted drug delivery systems. J Pharm Pharm Sci. Jan-Apr, 2003; 6(1); 33-66. PMID: 12753729. 